\title{
Kesalahan siswa dalam menyelesaikan soal operasi bilangan model ujian negara tingkat SMP
}

\author{
Alfha Vionita ${ }^{1,}$ a, *, Hartono ${ }^{2, b}$ \\ ${ }^{1}$ Program Studi S2 Pendidikan Matematika, Universitas Negeri Yogyakarta \\ Jl. Colombo No. 1, Karangmalang, Yogyakarta 55821, Indonesia \\ ${ }^{2}$ Jurusan Pendidikan Matematika, Universitas Negeri Yogyakarta \\ Jl. Colombo No. 1, Karangmalang, Yogyakarta 55821, Indonesia \\ E-mail: ${ }^{a}$ vionitaalfha@gmail.com, ${ }^{b}$ hartono@uny.ac.id \\ * Corresponding Author
}

\section{ARTICLE INFO}

\section{Article history}

Received: 20 Oct. 2017

Revised: 10 Sept. 2021

Accepted: 11 Sept. 2021

\section{Keywords}

analisis kesalahan, ujian negara, operasi bilangan, error analysis, state examination, number operation

Scan me:

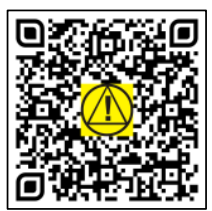

\section{ABSTRACT}

Penelitian ini bertujuan untuk mendeskripsikan jenis kesalahan siswa dalam menyelesaikan soal operasi bilangan model Ujian Negara (UN) untuk tingkat SMP. Penelitian ini termasuk penelitian survei dengan pendekatan kuantitatif. Survei dilaksanakan pada siswa SMP kelas IX se-Kabupaten Dharmasraya, Indonesia. Sampel penelitian sebanyak 104 siswa dipilih menggunakan teknik stratified propotional random sampling. Instrumen penelitian menggunakan tes diagnostik berupa soal uraian yang dimodifikasi dari soal pilihan ganda pada UN tingkat SMP. Hasil penelitian menunjukkan bahwa jenis kesalahan siswa dalam menyelesaikan soal operasi bilangan model UN untuk tingkat SMP yaitu kesalahan membaca (reading erorrs) sebanyak 30\%; kesalahan pemahaman (comprehension errors) sebanyak 40\%; kesalahan transformasi (transformations errors) sebanyak 83\%; kesalahan keterampilan proses (processing skill errors) sebanyak $85 \%$; dan kesalahan menarik kesimpulan (encoding errors) sebanyak $85 \%$.

This study aimed to describe the types of students' errors in solving the number operation problem of the state examination (Ujian Negara or UN) model for the junior high school level. This study was a survey with a quantitative approach. The survey was conducted on ninth-grade junior high school students in Dharmasraya Regency, Indonesia. The number of study samples was 104 students who were selected using the stratified proportional random sampling technique. The instrument used was a diagnostic test in the form of an essay problem which was modified from the multiple-choice national examination test at the junior high school level. The results showed that the types of students' errors in solving the UN model problem on the topic of number operations were: reading errors (30\%); comprehension error (40\%); transformations errors (83\%); processing skill errors (85\%); and encoding errors (85\%).

This is an open access article under the CC-BY-SA license.

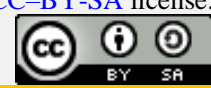

How to Cite: Vionita, A., \& Hartono, H. (2021). Kesalahan siswa dalam menyelesaikan soal operasi bilangan model ujian negara tingkat SMP. Jurnal Riset Pendidikan Matematika, 8(1), 117-127.

https://doi.org/10.21831/jrpm.v8i1.16447

\section{PENDAHULUAN}

Kualitas pendidikan dapat dilihat dari kompetensi lulusan dalam satuan pendidikan. Peranan matematika dalam pendidikan tidak terlepas dari upaya pemerintah dalam memperbaiki kualitas pendidikan di Indonesia. Dalam Peraturan Menteri Pendidikan dan Kebudayaan Republik Indonesia Nomor 59 Tahun 2014 disebutkan bahwa matematika merupakan ilmu universal yang berguna bagi kehidupan manusia dan juga mendasari perkembangan teknologi modern, serta mempunyai peran penting dalam berbagai disiplin ilmu dan memajukan daya pikir manusia (Kemendikbud, 2014). Kualitas pendidikan matematika di Indonesia dapat dilihat dari hasil belajar siswa yang diukur melalui 
evaluasi pendidikan yang diselenggarakan oleh pemerintah setiap tahunnya. Mekanisme penilaian hasil belajar oleh pemerintah tercantum pada Peraturan Menteri Pendidikan dan Kebudayaan Nomor 23 Tahun 2016 pasal 11, yaitu: (a) penilaian hasil belajar oleh Pemerintah dilakukan dalam bentuk Ujian Nasional (UN) dan/atau bentuk lain dalam rangka pengendalian mutu pendidikan, (b) penyelenggaraan UN oleh Badan Standar Nasional Pendidikan (BSNP) bekerja sama dengan instansi terkait untuk mengukur pencapaian kompetensi lulusan (Kemendikbud, 2016b).

Matematika menjadi salah satu mata pelajaran yang diujikan pada UN dan sebagai salah satu syarat penentu dalam kelulusan siswa. Siswa dinyatakan lulus dalam menyelesaikan suatu jenjang pendidikan apabila siswa tersebut mampu mendapatkan nilai matematika yang sesuai dengan standar yang ditentukan. Standar kelulusan siswa setiap tahunnya juga semakin tinggi. Hal ini menuntut siswa untuk mampu menguasai mata pelajaran matematika dengan baik dan benar demi tercapainya hasil belajar yang maksimal. Dalam pembelajaran matematika di jenjang Sekolah Menengah Pertama (SMP) disesuaikan dengan perkembangan intelektual siswa yang nantinya akan mempermudah siswa dalam memahami materi matematika pada jenjang selanjutnya.

Peraturan Menteri Pendidikan dan Kebudayaan Nomor 20 Tahun 2016 tentang standar kompetensi lulusan pendidikan dasar dan menengah menyebutkan bahwa setiap lulusan satuan pendidikan dasar dan menengah memiliki kompetensi pada tiga dimensi yaitu sikap, pengetahuan dan keterampilan (Kemendikbud, 2016a). Setiap siswa wajib mengikuti UN dalam rangka mengukur pencapaian kompetensi lulusan secara nasional. Kementerian Pendidikan dan Kebudayaan (Kemendikbud) melaporkan bahwa hasil UN tingkat SMP sederajat pada tahun 2016 secara nasional mengalami penurunan, khususnya pada matematika penurunan rerata nilai hingga 6,04 poin. Menurut Menteri Pendidikan dan Kebudayaan (Wurinanda, 2016) penurunan capaian tersebut dikarenakan kisi-kisi UN yang tidak lagi rinci serta peningkatan jumlah soal menalar. Penyelesaian soal matematika tidak hanya membutuhkan kemampuan menghitung namun juga dibutuhkan daya nalar yang membuat siswa mampu mengetahui apa yang dimaksud dari isi soal tersebut.

Pencapaian hasil nilai UN dapat dilihat berdasarkan provinsi, kabupaten, ataupun sekolah. Berdasarkan laporan hasil UN SMP/MTs se-Kabupaten Dharmasraya oleh BSNP tahun 2013 sampai 2016 (BSNP, 2013, 2014, 2015, 2016) pada penguasaan materi soal matematika empat tahun terakhir tergolong rendah. Mata pelajaran matematika memiliki rata-rata hasil belajar paling rendah dibandingkan dengan tiga mata pelajaran lainnya. Rendahnya rata-rata nilai matematika tersebut tidak terlepas dari rendahnya daya serap siswa pada penguasaan materi soal. Pada UN terdapat 25 indikator materi yang diujikan yaitu materi pokok operasi bilangan, operasi aljabar, geometri dan pengukuran, serta statistika dan peluang. Persentase daya serap materi operasi bilangan selama 4 tahun terakhir masih di bawah 50\% sehingga tergolong rendah yaitu secara berturut-turut UN 2012/2013 (43,28\%), UN 2013/2014 (38,25\%), UN 2014/2015 (45,21\%), dan UN 2015/2016 (36,51\%) (BSNP, 2013, 2014, 2015, 2016). Sedangkan berdasarkan indikator materi pada operasi bilangan tentang menyelesaikan masalah yang berkaitan dengan barisan bilangan dan deret semakin menurun persentasenya dibandingkan indikator materi lainnya, terlihat dari 3 tahun terakhir hasil UN 2012/2013 sampai 2014/2015 persentasenya berturut-turut $43,17 \% ; 42,22 \%$; dan $34,57 \%$ sehingga tergolong indikator materi yang sulit.

Rendahnya persentase daya serap siswa dalam penguasaan materi dapat disebabkan karena siswa banyak melakukan kesalahan dalam menyelesaikan soal. Pada saat siswa diberikan suatu permasalahan matematika yang sedikit berbeda dengan contoh yang telah diberikan guru maka banyak siswa menyelesaikannya dengan menggunakan pengetahuannya sendiri yang terkadang kurang sesuai dengan prosedur yang telah ada. Dari sinilah terjadi kesalahan pada saat menyelesaikan permasalahan matematika. Pada kenyataan di lapangan, hasil wawancara dengan guru SMP di Kabupaten Dharmasraya bahwa pada saat proses pembelajaran, siswa sulit untuk menguasai materi dikarenakan kurangnya waktu dan banyaknya materi yang diujikan.

Penguasaan materi yang kurang baik dapat membuat siswa mengalami kesulitan pada saat mengerjakan soal-soal matematika. Kesulitan tersebut dapat berhubungan dengan pengalaman siswa dalam pembelajaran matematika seperti yang dipaparkan oleh Radatz (Blanco \& Garrote, 2007, p. 222) tentang kesulitan siswa dalam menyelesaikan matematika adalah hasil atau produk dari pengalaman pembelajaran matematika sebelumnya. Hal ini dapat berarti kesulitan siswa dapat menyebabkan siswa melakukan kesalahan dalam menyelesaikan soal matematika sehingga memperoleh hasil yang kurang optimal. Suwarto (2013, p. 87) menyatakan bahwa kesulitan belajar adalah kegagalan dalam mencapai tujuan belajar, ditandai dengan hasil belajar yang rendah. 
Hasil penelitian oleh Isgiyanto (2011) menunjukkan bahwa kesalahan yang dapat terjadi pada siswa dalam mengerjakan soal UN matematika antara lain: kesalahan konsep dan kesalahan interpretasi bahasa. Hasil penelitian lain yaitu Prakitipong dan Nakamura (2006, p. 119) melaporkan bahwa siswa melakukan kesalahan pada pertanyaan pilihan ganda pada umumnya terletak pada tahap proses matematika yang berupa transformasi, proses keterampilan dan tingkat penyelesaian, sedangkan pada pertanyaan terstruktur terletak pada tahap tingkat pemahaman.

Kesalahan siswa perlu dianalisis untuk mengetahui jenis kesalahan yang dilakukan siswa sehingga guru dapat memberikan jenis bantuan yang sesuai terhadap siswa. Analisis kesalahan siswa ini juga mampu memberi gambaran yang jelas dan rinci atas kelemahan siswa dalam menyelesaikan persoalan matematika. Analisis dilakukan pada lembar respon siswa/lembar jawaban siswa dalam menyelesaikan soal UN matematika. Menurut Leighton et al. (Leighton \& Gierl, 2007, p. 62) metode diagnostik digunakan untuk mengetahui kekuatan-kekuatan dan kelemahan-kelemahan (strengths and weaksness) peserta tes.

Kesalahan bukanlah suatu hal yang negatif, namun dengan mengetahui kesalahan yang dilakukan maka mampu mengambil manfaat tersebut untuk memperbaiki jalannya proses pembelajaran di masa mendatang. Kesalahan matematika yang sistematis menunjukkan bahwa seorang siswa tidak mengerti apa yang sedang dipelajarinya atau sedang dikerjakannya. Kesalahan-kesalahan tersebut harus diidentifikasi sehingga diharapkan dapat membantu guru merencanakan program perbaikan selanjutnya. Smith et al. (2011, p. 19) menyatakan bahwa "the term 'learning difficuly' has been used to describe the significant minority of students who do seem to respond to their classroom programs".

Kesalahan dalam menyelesaikan soal dapat terjadi karena siswa dihadapkan dengan soal-soal yang menurut mereka soal yang sulit. Sebagai contoh, misalkan pada soal pertama siswa melakukan kesalahan dalam operasi penjumlahan bilangan bulat. Selanjutnya pada soal kedua siswa melakukan kesalahan pada operasi pembagian bilangan bulat. Maka dari kedua kesalahan tersebut dapat disimpulkan bahwa siswa melakukan kesalahan yang sama mengenai proses operasi bilangan bulat. Konsep dan prinsip merupakan pengetahuan dasar matematika yang harus dikuasai siswa supaya mereka mampu menyelesaikan persoalan matematika dengan baik dan benar. Untuk mengetahui pengetahuan siswa tentang kedua hal tersebut kepada siswa maka perlu diberikan persoalan-persoalan matematika yang harus diselesaikannya (Cooney et al., 1975, pp. 203-205). Kesalahan siswa dapat dilihat dari hasil penyelesaian persoalan matematika (tertulis) yang dibuatnya. Barbu and Beal (2010, p. 7) mengatakan bahwa kompleksitas bahasa juga memiliki pengaruh signifikan terhadap persepsi siswa tentang kesalahan dalam menyelesaikan soal cerita yang terkait dengan pemahaman teks. Pada penelitian ini soal yang diberikan kepada siswa berupa tes diagnostik soal model UN berbentuk soal uraian. Soal model UN merupakan soal yang mengacu pada indikator materi UN pada jenjang SMP/MTs pada tahun pelajaran 2012/2013 hingga tahun 2014/2015. Tes diagnostik yang dibuat setara dengan soal UN karena merupakan modifikasi dari soal-soal UN pilihan ganda menjadi soal uraian supaya lebih mudah dianalisis proses penyelesaian pekerjaan siswa.

Berdasarkan hasil penelitian Rumasoreng dan Sugiman (2014) tentang kesulitan matematika siswa dalam menyelesaikan soal setara UN di Kabupaten Maluku Tengah, ditemukan bahwa tingkat kesulitan terjadi pada kesulitan keterampilan, konsep, dan prinsip. Kesulitan siswa juga bisa saja berasal dari kesalahan-kesalahan yang dilakukan oleh siswa dalam memahami perspektif yang dibuat oleh guru mereka di dalam penyajian dan pemahaman masalah kata, membuat suatu rencana, dan melukiskan kosa kata yang terkait (Azis \& Sugiman, 2015, p. 164).

Analisis kesalahan siswa pada penelitian ini mengacu pada jenis kesalahan yang dikemukakan oleh Newman. Suyitno (2015, p. 529) menyatakan bahwa prosedur Newman banyak digunakan dan diterapkan di berbagai negara dan digunakan untuk menentukan berbagai jenis kesalahan siswa dalam menyelesaikan masalah matematika. Prakitipong dan Nakamura (2006, p. 113) juga berpendapat bahwa prosedur Newman merupakan suatu metode yang menganalisis kesalahan dalam kalimat permasalahan. Newman (White, 2005, p. 17) mengklasifikasikan kesalahan-kesalahan yang dilakukan siswa dalam menyelesaikan soal-soal matematika meliputi: reading errors merupakan kesalahan yang terjadi karena siswa tidak mampu membaca kata kunci atau simbol pada soal sehingga siswa tidak dapat melangkah lebih lanjut pada pola pemecahan masalah yang tepat. Comperhension errors merupakan kesalahan yang terjadi dimana siswa sudah mampu membaca semua kata pada soal, tetapi tidak menguasai secara menyeluruh pengertian kata-kata tersebut, sehingga siswa tidak mampu melangkah lebih lanjut pada pola pemecahan masalah yang tepat. Transformations erorrs merupakan kesalahan yang terjadi dimana 
siswa telah memahami apa yang diinginkan soal akan tetapi tidak mampu mengidentifikasi operasi atau pola operasi yang dibutuhkan untuk memecahkan masalah. Processing skill errors merupakan kesalahan yang terjadi dimana siswa telah mengidentifikasi operasi atau pola operasi yang tepat, akan tetapi tidak mengetahui prosedur yang diperlukan untuk menyelesaikan operasi tersebut secara akurat. Encoding errors merupakan kesalahan yang terjadi dimana siswa telah menemukan solusi atau permasalahan, akan tetapi salah dalam menuliskan jawaban akhir.

Berdasarkan latar belakang masalah dan kajian teori yang telah dikemukakan, maka penelitian ini bertujuan untuk mendeskripsikan jenis kesalahan yang dilakukan oleh siswa dalam menyelesaikan soal operasi bilangan model ujian negara jenjang SMP se-Kabupaten Dharmasaraya. Temuan penelitian diharapkan dapat menjadi rujukan dalam upaya meningkatkan mutu pendidikan khususnya dalam pembelajaran matematika pada aspek kognitif.

\section{METODE}

Penelitian survei ini bertujuan untuk menggali informasi yang beraneka ragam terkait kesalahan siswa dalam menyelesaikan soal. Penelitian ini dilaksanakan di empat SMP di Kabupaten Dharmasraya, Sumatera Barat, Indonesia. Pengambilan sampel dilakukan dengan menggunakan teknik sampel acak proporsional berstrata (stratified proportional random sampling) yang merupakan gabungan dari teknik sampling bertingkat (stratified sampling) dan teknik sampling proporsional (proportional sampling) yang dilanjutkan dengan teknik sampling acak (random sampling). Teknik sampling proporsional digunakan untuk menentukan sampel secara proporsional untuk setiap strata. Dari 50 sekolah di Kabupaten Dharmasraya dengan jumlah populasi sebanyak 2608 siswa maka didapatkan sampel pada penelitian ini sebanyak 104 siswa yang terbagi pada empat sekolah, yaitu satu sekolah kategori tinggi (sebanyak 28 siswa), dua sekolah kategori sedang (sebanyak 51 siswa), dan satu sekolah kategori rendah (sebanyak 25 siswa).

Teknik pengumpulan data yang digunakan dalam penelitian adalah tes diagnostik yang digunakan untuk mengumpulkan data tentang jawaban dan langkah pengerjaan yang dilakukan siswa dalam menyelesaikan soal. Instrumen tes diagnostik berupa soal model UN yang berbentuk soal uraian supaya lebih mudah menganalisis kesalahan siswa dari hasil kerja siswa dalam menyelesaikan soal. Kisi-kisi soal sesuai dengan indikator UN pada materi operasi bilangan tentang menyelesaikan masalah yang berkaitan dengan barisan bilangan dan deret. Peneliti membuat dua soal yang berbeda supaya lebih terlihat pada soal materi mana siswa masih sulit menyelesaikannya. Soal 1 tentang barisan dan deret aritmetika dengan indikator soal yaitu diberikan barisan aritmetika yang diketahui suku ke- $p$ dan suku ke- $q$, siswa menentukan jumlah $n$ suku pertama deret tersebut. Soal 2 tentang barisan dan deret geometri dengan indikator soal yaitu diberikan masalah yang berkaitan dengan barisan geometri yang diketahui suku pertama dan suku ke- $n$, siswa menentukan jumlah suku sampai suku ke- $n$ deret geometri. Pada lembar jawaban, siswa diminta menuliskan apa yang diketahui pada soal, apa yang ditanyakan pada soal, kemudian menuliskan uraian dari jawaban dan terakhir siswa diminta menyimpulkan tentang pekerjaannya.

Pada penelitian ini, validitas instrumen dibuktikan melalui validitas isi dengan meminta masukan dari dua dosen ahli matematika. Hasil validasi menunjukkan bahwa instrumen tes diagnostik soal model UN pada materi operasi bilangan dinyatakan valid oleh ahli. Hasil estimasi reliabilitas menunjukkan bahwa instrumen tes diagnostik memiliki koefisien reliabilitas sebesar 0,816 yang berada pada kategori sangat tinggi.

Analisis data yang digunakan berupa analisis statistik deskriptif. Analisis berupa deskripsi hasil tes diagnostik yang diperiksa dengan melihat penyelesaian soal oleh siswa (menjawab benar, benar tetapi kurang lengkap, salah menyelesaikan, tidak selesai, atau tidak mengerjakan). Jawaban siswa dalam mengerjakan tes diagnostik yang berbentuk uraian, diperiksa berdasarkan skor kesalahan siswa yang ditentukan dengan menggunakan pedoman penskoran tes diagnostik. Selanjutnya jawaban siswa yang salah dianalisis dengan menggunakan coding scheme (skema pengkodean) yang dikembangkan dari jenis kesalahan Newman (Jha, 2012; Singh et al., 2010). Skema pengkodean yang dimaksud disajikan pada Tabel 1. 
Tabel 1. Skema pengkodean kesalahan siswa

\begin{tabular}{ll}
\hline Jenis kesalahan & Keterangan \\
\hline Membaca & Siswa salah memaknai arti setiap kata, istilah atau simbol dalam soal. \\
Pemahaman & Siswa tidak dapat memahami apa saja yang diketahui dan ditanyakan pada \\
Transformasi & Soal dengan lengkap. \\
& $\begin{array}{l}\text { Siswa tidak dapat membuat model/rumus matematis. } \\
\text { Siswa tidak mengetahui prosedur/langkah yang akan digunakan untuk } \\
\text { menyelesaikan soal dengan tepat. }\end{array}$ \\
Keterampilan proses & $\begin{array}{l}\text { Siswa tidak dapat melanjutkan prosedur/langkah penyelesaian. Siswa } \\
\text { melakukan kesalahan dalam melakukan komputasi. }\end{array}$ \\
Menarik kesimpulan & $\begin{array}{l}\text { Siswa tidak dapat menemukan hasil akhir sesuai prosedur/langkah yang } \\
\text { digunakan atau tidak dapat menuliskan jawaban akhir sesuai yang } \\
\text { dimaksud soal. }\end{array}$ \\
\hline
\end{tabular}

Selain itu, uji pengkodean jenis kesalahan dilakukan dengan menggunakan inter-rater reliability. Pengujian untuk analisis lembar jawaban siswa dalam menyelesaikan soal operasi bilangan model UN yaitu observasi yang dilakukan oleh dua orang rater atau observer pada sampel yang sama. Dari hasil output analisis nilai koefisien Cohen's Kappa menunjukkan bahwa rata-rata kesepakatan antar rater sebesar 0,916 yang berati bahwa nilai kesepakatan antar rater sangat tinggi. Selanjutnya, berdasarkan analisis terhadap data hasil tes diagnostik dilakukan penarikan kesimpulan berupa deskripsi terkait jenis kesalahan yang dilakukan subyek penelitian dalam menyelesaikan soal matematika model UN.

\section{HASIL DAN PEMBAHASAN}

Dalam penelitian ini hasil jawaban tes diagnostik siswa dideskripsikan dan dianalisis jenis kesalahannya berdasarkan kriteria Newman. Jawaban dari 104 siswa dikoreksi berdasarkan banyaknya siswa menjawab benar, benar tetapi kurang lengkap, salah menyelesaikan, tidak mengerjakan, dan tidak selesai, seperti tertera pada Tabel 2. Masing-masing siswa diberikan tes diagnostik yang terdiri dari 2 butir soal tentang operasi bilangan sehingga didapatkan 208 hasil pekerjaan siswa.

Tabel 2. Hasil jawaban tes diagnostik $(n=104)$ dalam menyelesaikan soal materi operasi bilangan

\begin{tabular}{lcc}
\hline Penyelesaian siswa & Jumlah jawaban & Persentase (\%) \\
\hline Benar menyelesaikan (BN) & 18 & 9 \\
Benar tetapi kurang lengkap (BTK) & 13 & 6 \\
Salah menyelesaikan (SM) & 114 & 55 \\
Tidak mengerjakan (TM) & 9 & 4 \\
Tidak selesai (TS) & 54 & 26 \\
Total & 208 & 100 \\
\hline
\end{tabular}

Selain dideskripsikan hasil jawaban dari tes diagnostik siswa, juga dideskripsikan skor kesalahan siswa berdasarkan pedoman skor kesalahan yang telah dibuat. Pedoman penskoran dibuat sesuai dengan kriteria kesalahan dari Newman dengan skor 0 jika benar menyelesaikan, skor 1 jika salah menyelesaikan, skor 2 jika tidak menyelesaikan di setiap kriteria. Rata-rata skor kesalahan yang paling dominan yaitu pada kesalahan menarik kesimpulan sebesar 0,6 dan diikuti rata-rata kesalahan keterampilan proses dan kesalahan transformasi sebesar 0,5. Selanjutnya rata-rata kesalahan pemahaman dan kesalahan membaca sebesar 0,2 .

Tabel 3 mendeskripsikan persentase jenis kesalahan siswa, di mana paling dominan siswa melakukan kesalahan pada jenis kesalahan keterampilan proses dan kesalahan menarik kesimpulan. Sedangkan Tabel 4 mendeskripsikan jenis kesalahan berdasarkan kategori sekolah. Berdasarkan Tabel 4, kategori sekolah berstrata tinggi yang paling dominan berada pada jenis kesalahan keterampilan proses dan kesalahan menarik kesimpulan sebesar $84 \%$. Kategori sekolah berstrata sedang yang paling dominan juga berada pada jenis kesalahan keterampilan proses dan kesalahan menarik kesimpulan sebesar 86\%. Sedangkan kategori sekolah berstrata rendah yang paling dominan berada pada jenis kesalahan transformasi sebesar $88 \%$ dan diikuti kesalahan menarik kesimpulan dan kesalahan keterampilan proses sebesar $84 \%$. Dengan demikian, kategori sekolah berstrata rendah masih tergolong rendah dalam 
menyelesaikan soal operasi bilangan dibandingkan sekolah berstrata tinggi dan sedang. Jenis kesalahan yang paling dominan dari ketiga strata tersebut berada pada jenis kesalahan menarik kesimpulan.

Tabel 3. Persentase jenis kesalahan siswa berdasarkan tes diagnostik $(n=104)$ pada materi operasi bilangan

\begin{tabular}{lcc}
\hline Jenis kesalahan & Jumlah & Persentase (\%) \\
\hline Kesalahan membaca (KM) & 63 & 30 \\
Kesalahan pemahaman (KP) & 83 & 40 \\
Kesalahan transformasi (KT) & 173 & 83 \\
Kesalahan keterampilan proses (KTP) & 176 & 85 \\
Kesalahan menarik kesimpulan (KMP) & 177 & 85 \\
\hline
\end{tabular}

Tabel 4. Persentase jenis kesalahan siswa pada materi operasi bilangan berdasarkan kategori sekolah

\begin{tabular}{lccc}
\hline \multirow{2}{*}{ Jenis kesalahan } & \multicolumn{3}{c}{ Kategori sekolah } \\
\cline { 2 - 4 } & Tinggi $(\%)$ & Sedang $(\%)$ & Rendah $(\%)$ \\
\hline KM & 18 & 30 & 44 \\
KP & 25 & 42 & 52 \\
KT & 79 & 83 & 88 \\
KTP & 84 & 86 & 84 \\
KMP & 84 & 86 & 84 \\
\hline
\end{tabular}

Tabel 5. Persentase jenis kesalahan siswa berdasarkan indikator materi pada operasi bilangan $(n=104)$

\begin{tabular}{lcc}
\hline Jenis kesalahan & Soal 1 $(\%)$ & Soal 2 $(\%)$ \\
\hline Kesalahan membaca & 33 & 28 \\
Kesalahan pemahaman & 45 & 35 \\
Kesalahan transformasi & 90 & 76 \\
Kesalahan keterampilan proses & 87 & 87 \\
Kesalahan menarik kesimpulan & 83 & 84 \\
\hline
\end{tabular}

Tabel 5 menunjukkan bahwa pada soal 1 dengan indikator soal tentang barisan aritmetika yang diketahui suku ke- $p$ dan suku ke- $q$, siswa menentukan jumlah $n$ suku pertama deret tersebut, terlihat bahwa persentase yang paling dominan pada jenis kesalahan transformasi sebesar $90 \%$ dan diikuti jenis kesalahan keterampilan proses sebesar $87 \%$. Sedangkan pada soal 2 dengan indikator soal tentang masalah yang berkaitan dengan barisan geometri yang diketahui suku pertama dan suku ke- $n$, siswa menentukan jumlah suku sampai suku ke- $n$ deret geometri terlihat yang paling dominan jenis kesalahan keterampilan proses sebesar $87 \%$ dan diikuti jenis kesalahan menarik kesimpulan sebesar $84 \%$.

\section{Pembahasan}

Jenis kesalahan membaca yang dilakukan siswa dalam menyelesaikan tes diagnostik merupakan jenis kesalahan yang persentasenya paling sedikit dibandingkan jenis kesalahan lainnya. Hal ini dapat disebabkan karena soal dibuat dalam bahasa Indonesia, kata-kata yang digunakan juga tidak menggunakan istilah asing. Meskipun demikian masih ada beberapa siswa yang mengalami kebingungan dalam mencari kata kunci atau simbol pada soal. Kesalahan dalam memaknai kalimat pada soal dapat membuat siswa kesulitan menemukan kata kunci untuk menyelesaikan soal tersebut.

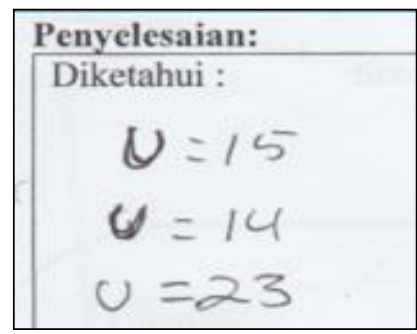

Gambar 1. Kesalahan siswa membaca kata kunci/simbol pada soal 1

Pada Gambar 1 terlihat siswa menulis " $U=15, U=14, U=23$ ", hal ini menunjukkan siswa salah dalam menulis kata kunci/simbol yang ada pada soal. Seharusnya siswa menuliskan dengan 
lengkap "suku ke-5 dan suku ke- 8 barisan aritmetika berturut-turut 14 dan 23 " yaitu " $U_{5}=14$ dan $U_{8}=$ 23". Hal tersebut mengindikasikan bahwa siswa belum mampu mengetahui simbol dari "suku ke-" atau " $U_{n}$ ".

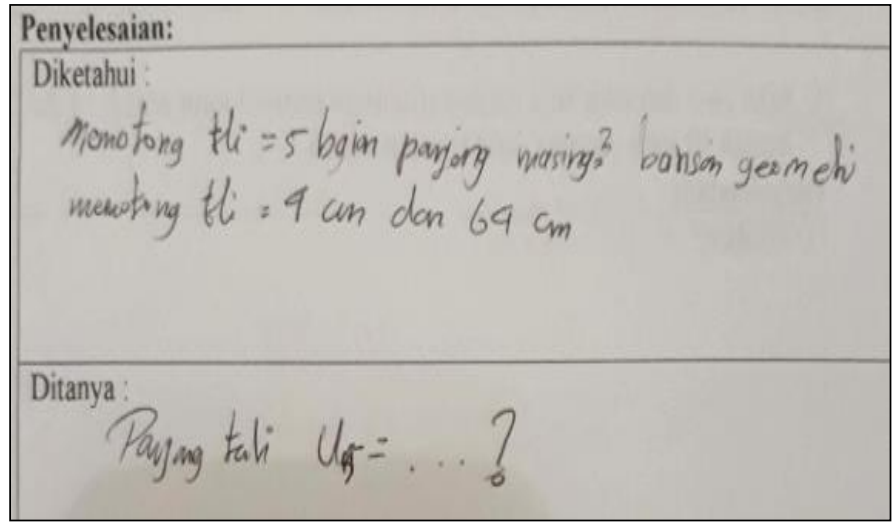

Gambar 2. Kesalahan siswa membaca kata kunci/simbol dan pemahaman pada soal 2

Pada Gambar 2 tidak jelas maksud tulisan yang disajikan siswa pada kolom diketahui dan siswa juga menuliskan simbol $U_{5}$ tidak sesuai dengan informasi yang ada pada soal 2. Seharusnya siswa menuliskan dengan tepat " $U_{1}=4$ dan $U_{5}=64$ " pada kolom diketahui, sedangkan pada kolom ditanya seharusnya menuliskan " $S_{5}$ ". Gambar 2 juga menunjukkan bahwa jawaban siswa masuk ke dalam jenis kesalahan pemahaman karena siswa salah dalam memahami apa saja yang diketahui dan ditanyakan pada soal.

Jenis kesalahan pemahaman yaitu kesalahan menentukan apa yang diketahui dan kesalahan menentukan apa yang ditanya pada soal. Kesalahan tersebut dapat dilihat dari hasil pekerjaan siswa yakni siswa membaca soal namun tanpa memahami informasi apa saja yang didapatkan dari soal sehingga siswa hanya asal menuliskan apa yang diketahui atau apa yang ditanya pada soal. Hal ini sesuai dengan pernyataan Newman (White, 2005, p. 17) yaitu siswa mampu membaca semua kata pada soal, namun tidak menguasai pengertian kata-kata tersebut.

Kesalahan selanjutnya yaitu jenis kesalahan transformasi yaitu siswa salah atau bahkan tidak bisa menentukan langkah-langkah yang akan digunakan untuk menyelesaikan soal. Selain itu ada juga siswa yang hanya menuliskan rumusnya saja tanpa menentukan sistem penyelesaian selanjutnya seperti apa. Pada soal 1 tentang barisan dan deret aritmetika, kesalahan ini termasuk yang paling dominan dibandingkan kesalahan lainnya. Hal ini sejalan dengan temuan penelitian Wijaya et al. (2014) yang mengungkapkan bahwa kesalahan pemahaman dan transformasi paling dominan dilakukan oleh siswa. Siswa lebih sedikit membuat kesalahan dalam pengolahan matematika dan penafsiran solusi matematika dalam situasi dunia nyata.

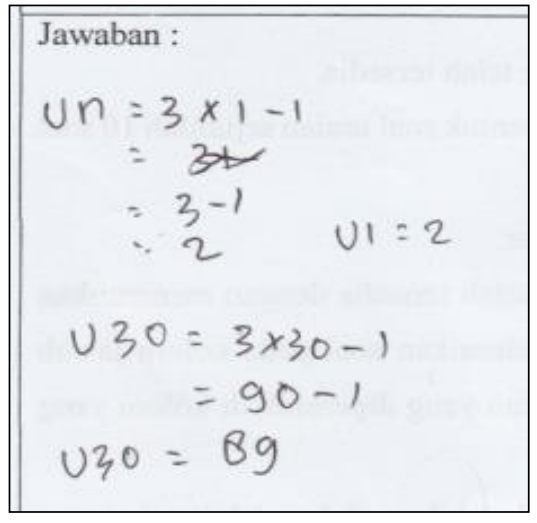

Gambar 3. Kesalahan siswa dalam transformasi pada soal 1

Gambar 3 menunjukkan siswa tidak mampu menentukan langkah penyelesaian dalam menyelesaikan butir soal 1 tentang jumlah $n$ suku pertama deret aritmetika. Siswa hanya menuliskan tentang 
" $U_{n}$ " dan langkah yang ditulis tidak jelas karena rumus yang digunakan juga salah sehingga mengakibatkan langkah penyelesaian selanjutnya tidak sesuai dengan yang diharapkan pada soal.

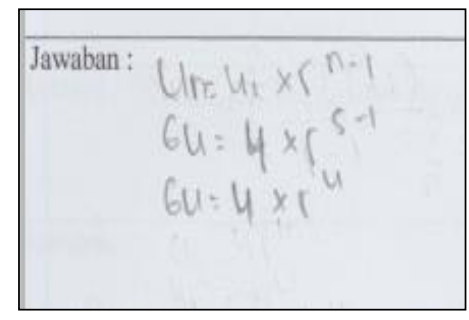

Gambar 4. Kesalahan siswa dalam transformasi pada soal 2

Gambar 4 menunjukkan salah satu contoh jawaban siswa yang salah dalam transformasi yaitu salah menentukan langkah penyelesaian soal 2 . Siswa dalam penyelesaian langsung menulis rumus " $U_{n}$ " barisan geometri dan tidak menyelesaikannya sampai selesai untuk mencari rumus jumlah suku ke- $n$ deret geometri, seharusnya setelah menulis rumus " $U_{n}$ " barisan geometri untuk mencari nilai $r$, dilanjutkan dengan menuliskan rumus jumlah suku ke- $n$ deret geometri yaitu $S_{n}=\frac{a\left(r^{n}-1\right)}{r-1}$ dengan $r>1$ untuk mencari panjang tali semula yang ditanyakan pada butir soal 2.

Jenis kesalahan pada tahap keterampilan proses yang dilakukan siswa yakni siswa tidak mampu menggunakan informasi yang ada pada soal untuk menyelesaikan soal, tidak melakukan tahapan dengan lengkap sehingga jawaban yang ditemukan tidak lengkap, kesalahan dalam memproses bilangan, dan kesalahan dalam memproses variabel. Hal ini sesuai dengan pendapat Singh et al. (2010, p. 266) bahwa kesalahan keterampilan proses terjadi apabila siswa mampu memilih operasi yang diperlukan untuk menyelesaikan persoalan, namun ia tak dapat menjalankan prosedur dengan benar, seperti halnya menggunakan informasi yang ada pada soal.

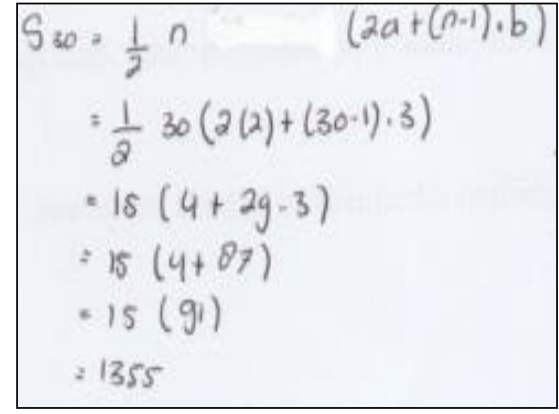

Gambar 5. Kesalahan siswa dalam keterampilan proses pada soal 1

Gambar 5 menunjukkan tentang kesalahan siswa dalam menyelesaikan operasi hitung matematika pada soal 1. Pada gambar tersebut terlihat bahwa siswa tidak mampu menerapkan keterampilan proses dengan benar dalam menyelesaikan operasi hitung matematika. Siswa salah dalam mengalikan $15 \times 91$ $=1355$, seharusnya hasilnya adalah 1365. Selanjutnya pada Gambar 6 terlihat kesalahan siswa dalam menyelesaikan operasi hitung matematika pada soal 2 yakni siswa salah dalam menyelesaikan perkalian di bagian akhir penyelesaian yaitu $4 \times 31=93$, seharusnya jawaban yang tepat adalah 124 . Dalam hal ini, siswa tidak mengecek kembali jawabannya apakah sudah benar atau salah.

Pada jenis kesalahan menarik kesimpulan termasuk jenis kesalahan dominan pada soal 1 dan soal 2. Prakitipong dan Nakamura (2006, p. 114) menyatakan bahwa siswa telah mampu mencapai tahap menarik kesimpulan apabila siswa dapat menuliskan jawaban dengan tepat dan lengkap. Dengan demikian, siswa dikatakan melakukan kesalahan dalam tahap ini jika siswa kurang lengkap dalam penulisan jawaban dari soal dengan tidak memberikan keterangan dari jawaban tersebut sesuai apa yang ditanyakan pada soal. Kesalahan ini dapat dilihat dari hasil pekerjaan siswa pada saat menuliskan jawaban akhir di kolom kesimpulan. Pada umumnya siswa dapat mengerjakan penyelesaian, tetapi terkadang ia tidak mampu mengekspresikan penyelesaian tersebut ke dalam kalimat matematika yang dapat diterima atau sesuai dengan yang ditanyakan pada soal. 


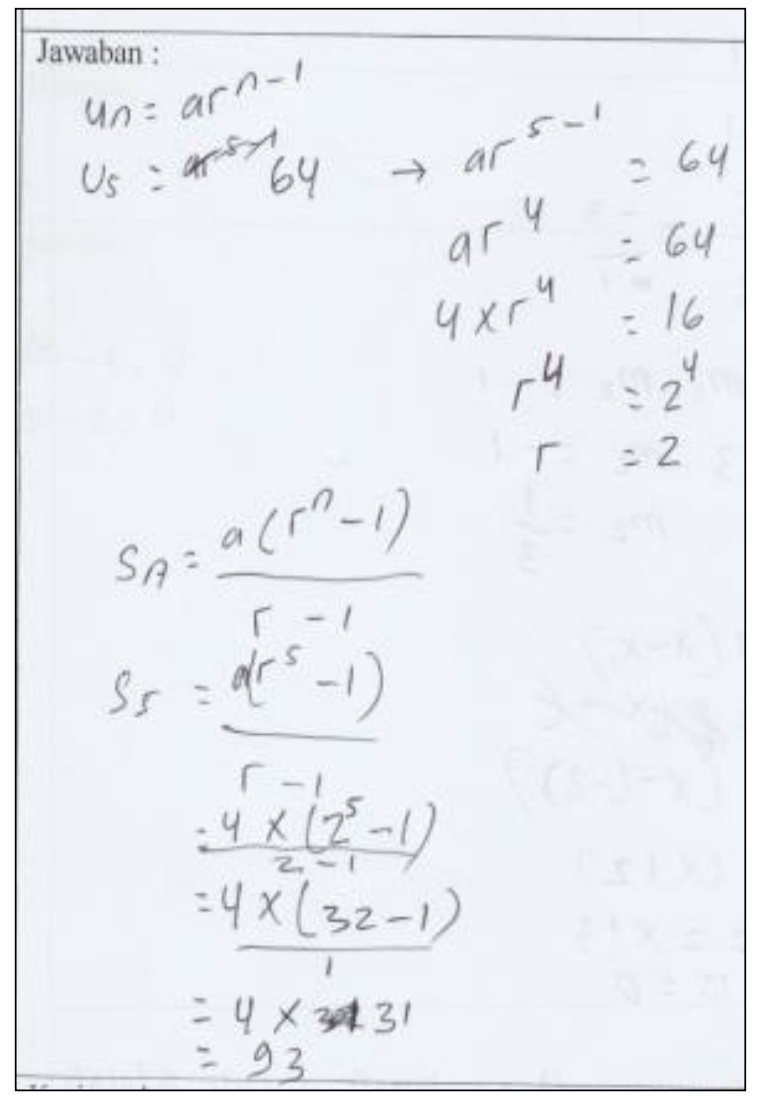

Gambar 6. Kesalahan siswa dalam keterampilan proses pada soal 2

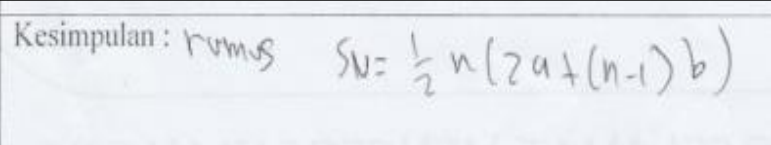

Gambar 7. Kesalahan siswa dalam menarik kesimpulan pada soal 1

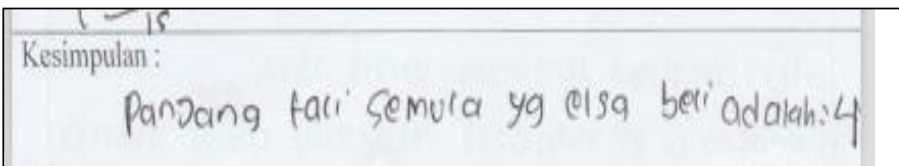

Gambar 8. Kesalahan siswa dalam menarik kesimpulan pada soal 2

Gambar 7 menunjukkan salah satu contoh pekerjaan siswa yang salah dalam menentukan solusi/ jawaban akhir pada butir soal 1. Terlihat bahwa siswa menuliskan rumus deret aritmetika yaitu $S_{n}=$ $\frac{1}{2} n(2 a+(n-1) b$, seharusnya siswa menuliskan hasil penyelesaian yang dibuat sesuai dengan yang ditanyakan pada soal tersebut. Gambar 8 memperlihatkan hasil pekerjaan siswa yang salah dalam penyelesaian butir soal 2. Siswa dalam menentukan jawaban akhir tanpa mengecek kembali penyelesaian yang dilakukan, apakah sudah tepat atau belum. Dengan demikian, terlihat bahwa siswa tidak mampu menganalisis hasil jawaban akhir yang diperoleh sehingga menyebabkan kesalahan dalam menentukan jawaban akhir.

\section{SIMPULAN}

Berdasarkan hasil penelitian dan pembahasan, maka dapat disimpulkan bahwa jenis kesalahan yang dilakukan oleh siswa dalam menyelesaikan soal operasi bilangan model ujian negara yaitu kesalahan membaca (reading erorrs) sebesar 30\%, kesalahan pemahaman (comprehension errors) sebesar 
$40 \%$, kesalahan transformasi (transformations errors) sebesar 83\%, kesalahan keterampilan proses (processing skill errors) dan kesalahan menarik kesimpulan (encoding errors) sebesar 85\%. Temuan tersebut mengindikasikan bahwa siswa masih mengalami kesulitan dalam menyelesaikan soal operasi bilangan model ujian negara. Berdasarkan temuan tersebut, disarankan kepada guru untuk dapat merancang desain pembelajaran matematika yang dapat melatihkan siswa dalam memecahkan masalah, khususnya terkait dengan aspek pemahaman, transformasi, keterampilan proses, dan penarikan kesimpulan. Selain itu, disarankan juga kepada peneliti lain untuk menggali aspek lain yang menjadi penyebab kesulitan siswa dalam menyelesaikan masalah matematika, baik ditinjau dari aspek kognitif maupun non kognitif.

\section{DAFTAR PUSTAKA}

Azis, A., \& Sugiman, S. (2015). Analisis kesulitan kognitif dan masalah afektif siswa SMA dalam belajar matematika menghadapi ujian nasional. Jurnal Riset Pendidikan Matematika, 2(2), 162 174. https://doi.org/10.21831/jrpm.v2i2.7331

Barbu, C. O., \& Beal, C. R. (2010). Effects of linguistic complexity and math difficulty on word problem solving by english learners. International Journal of Education, 2(2), 1-19. https://doi.org/10.5296/ije.v2i2.508

Blanco, L., \& Garrote, M. (2007). Difficulties in learning inequalities in student of first year of preuniversity education in Spain. Eurasia Journal of Mathematics, Science and Technology Education, 3(3), 221-229. https://doi.org/10.12973/ejmste/75401

BSNP. (2013). Panduan pemanfaatan hasil UN tahun pelajaran 2012/2013 untuk perbaikan mutu pendidikan. Pusat Penilaian Pendidikan, Kemendikbud.

BSNP. (2014). Panduan pemanfaatan hasil UN tahun pelajaran 2013/2014 untuk perbaikan mutu pendidikan. Pusat Penilaian Pendidikan, Kemendikbud.

BSNP. (2015). Panduan pemanfaatan hasil UN tahun pelajaran 2014/2015 untuk perbaikan mutu pendidikan. Pusat Penilaian Pendidikan, Kemendikbud.

BSNP. (2016). Panduan pemanfaatan hasil UN tahun pelajaran 2015/2016 untuk perbaikan mutu pendidikan. Pusat Penilaian Pendidikan, Kemendikbud.

Cooney, T. J., Davis, E. J., \& Henderson, K. B. (1975). Dinamics of teaching secondary school mathematics. Houghton Mifflin Company.

Isgiyanto, A. (2011). Analisis untuk menemukan informasi diagnostik data ujian nasional matematika sekolah menengah pertama [Doctoral dissertation, Universitas Negeri Yogyakarta]. https://eprints.uny.ac.id/42262/

Jha, S. K. (2012). Mathematics performance of primary school students in Assam (India): An analysis using Newman procedure. International Journal of Computer Applications in Engineering Sciences, 2(1), 17-21.

Kemendikbud. (2014). Peraturan Menteri Pendidikan dan Kebudayaan Republik Indonesia Nomor 59 Tahun 2014 tentang Kurikulum 2013 SMA/MA.

https://jdih.kemdikbud.go.id/arsip/Permendikbud\%20Nomor\%2059\%20Tahun\%202014.pdf

Kemendikbud. (2016a). Peraturan Menteri Pendidikan dan Kebudayaan Republik Indonesia Nomor 20 Tahun 2016 tentang Standar Kompetensi Lulusan Pendidikan Dasar dan Menengah. http://bsnpindonesia.org/wpcontent/uploads/2009/04/Permendikbud_Tahun2016_Nomor020_Lampiran.pdf

Kemendikbud. (2016b). Peraturan Menteri Pendidikan dan Kebudayaan Republik Indonesia Nomor 23 Tahun 2016 tentang Standar Penilaian Pendidikan. http://bsnpindonesia.org/wpcontent/uploads/2009/09/Permendikbud_Tahun2016_Nomor023.pdf

Leighton, J. P., \& Gierl, M. J. (2007). Cognitive diagnostic assessment for education. Cambridge University Press. 
Prakitipong, N., \& Nakamura, S. (2006). Analysis of mathematics performance of grade five students in Thailand using Newman procedure. Journal of International Cooperation in Education, 9(1), 111-122. http://doi.org/10.15027/34243

Rumasoreng, M. I., \& Sugiman, S. (2014). Analisis kesulitan matematika siswa SMA/MA dalam menyelesaikan soal setara UN di Kabupaten Maluku Tengah. Jurnal Riset Pendidikan Matematika, 1(1), 22-34. https://doi.org/10.21831/jrpm.v1i1.2661

Singh, P., Rahman, A. A., \& Hoon, T. S. (2010). The Newman procedure for analyzing primary four pupils errors on written mathematical task: A Malaysian perspective. Procedia Social and Behavioral Sciences, 8, 264-271. https://doi.org/10.1016/j.sbspro.2010.12.036

Smith, C. W., Elkins, J., \& Gunn, S. (2011). Multiple perspectives on difficulties in learning literacy and numeracy. Springer.

Suwarto, S. (2013). Pengembangan tes diagnostik dalam pembelajaran. Pustaka Belajar.

Suyitno, A. (2015). Learning therapy for students in mathematics communication correctly based-on application of Newman procedure (a case of Indonesia student). International Journal of Education and Research, 3(1), 529-538. https://ijern.com/journal/2015/January-2015/44.pdf

White, A. L. (2005). Active mathematics in classrooms finding out why children make mistakes and then doing something to help them. Journal of The Primary Association for Mathematics, 15(4), $15-19$.

Wijaya, A., van den Heuvel-Panhuizen, M., Doorman, M., \& Robitzsch, A. (2014). Difficulties in solving context-based PISA mathematics tasks: an analysis of students' errors. The Mathematics Enthusiast, 11(3), 555-584.

Wurinanda, I. (2016, June 10). Matematika paling sulit di UN SMP 2016. http://news.okezone.com 